\title{
Application of product development tools in equipment design for a technology-based small business
}

\author{
Aplicação das ferramentas de desenvolvimento de produto no \\ projeto de um equipamento para uma empresa de pequeno porte \\ de base tecnológica
}

\author{
Felipe Mello Pierobom ${ }^{1}$, Jairo José de Oliveira Andrade ${ }^{1}$ \\ ${ }^{1}$ Pontifícia Universidade Católica do Rio Grande do Sul - PUCRS, Escola Politécnica, Porto Alegre, RS, Brasil. \\ E-mail: felipe.pierobom@azanonatec.com.br; jairo.andrade@pucrs.br
}

How to cite: Pierobom, F. M., \& Andrade, J. J. O. (2020). Application of product development tools in equipment design for a technology-based small business. Gestão \& Produção, 27(2), e3849.

https://doi.org/10.1590/0104-530X3849-20

\begin{abstract}
The main objective of this paper is to use the techniques and methods of Product Process Development in the equipment development for a technology-based small business. Conceptual design concepts were generated and through the use of a morphological matrix the options of confection of the final conceptual prototype were verified. With the definition of the previous steps, the project team cataloged the main requirements and functions of the equipment and compared and evaluated them with a reference concept already used in the external environment of the company, verifying their priorities through the Mudge Method. Subsequently, the study of the needs of improvements in the main functions was done creating a final functional prototype for use in the work environment. The application of these techniques allowed quantifying the productivity of the product manufactured by equipment, comparing the situation before and after the process with the new equipment. In addition it was verified that when the process is carried out by the equipment developed there is a productivity improvement since this allowed to reduce the amount of losses; decrease production variability over time, since there is no operator wear and more results standardization.
\end{abstract}

Keywords: Product engineering; Product planning and development; Conceptual design.

Resumo: O principal objetivo desse artigo é empregar as técnicas e métodos do Processo de Desenvolvimento de Produto no desenvolvimento de um equipamento em uma pequena empresa de base tecnológica. Conceitos iniciais foram gerados e, empregando-se a Matriz Morfológica as opções para fabricação do protótipo funcional foram verificadas. Com as definições obtidas nas etapas anteriores, o time de projeto catalogou os principais requisitos e funções do equipamento, cujo mesmo foi comparado e avaliado com um conceito de referência, verificando-se as funções principais através da Matriz de Mudge. Na sequência, foram analisadas as necessidades de melhorias nas funções do produto, gerando um protótipo para emprego na empresa analisada. A aplicação dessas técnicas permitiram quantificar a produtividade do produto fabricado pelo equipamento, comparando-se tal indicador antes e depois. Pôde-se verificar que houve um significativo aumento de produtividade com consequente

Received Mar. 6, 2017 - Accepted Apr. 16, 2018

Financial support: None.

This is an Open Access article distributed under the terms of the Creative Commons Attribution License, which permits unrestricted use, distribution, and reproduction in any medium, provided the original work is properly cited. 
redução de perdas do processo, minimização da variabilidade do produto manufaturado ao longo do tempo, minimização dos esforços operacionais e uma maior padronização do processo.

Palavras-chave: Engenharia do Produto; Planejamento e Desenvolvimento do Produto; Projeto Conceitual.

\section{Introduction}

Nowadays, the competitive market demands success when launching new products. However, with the globalization effects, the resolution of specific problems in certain market depends on the efficiency and effectiveness of Product Planning and Development (PPD) process. Rozenfeld et al. (2006) have verified that a lot of technology-based companies seek PPD improvement in order to generate declining loss indices by the continual improvement of the final product manufacture. For example, there are the small companies of the Electro-electronic sector of Technological Base - ETB (Reis et al., 2014), that have been seeking to dedicate more attention to the development process of equipment that aim to increase productivity and optimize the production sector, currently seen as one of the main competitive advantage sources to create new ways to perform the internal manufacture processes and improve the ones already existent (Toledo et al., 2008).

In Brazil the ETBs are in need of studies focused on the equipment and products development management processes, since there's little knowledge targeted on this segment because those companies do not rely on big production levels (Jugend, 2006; Toledo et al., 2008; Conforto et al., 2011). Thus, the performance of the equipment development sector needs to be capable to conduct researches to seek sources with high technologic innovation power so that the equipment does not become obsolete and hard to maintain (Scoralick, 2004; Conforto et al., 2011).

The present paper focused on an small sized ETB located at Porto Alegre (RS, Brazil), and which elected to develop its own products and equipment's. The company has its production based on make to order and has the short delivery time as competitive edge, most of the times making next day deliveries. However, the biggest problem of product rework lies on bad connections generated by the crimping process (the activity of attaching a metallic terminal to the wire without the protective cap using pliers or cable glands as a crimping tool) due to the absence of an equipment that standardizes this operation, since this process is manually performed by the employees. The lack of quality standards is reflected in problems such as the breaking of plugs in the later stage of thermoplastic injection, generating delays in production. However, with a high degree of technology acquired by the company and although the activity of creating equipment for internal use is common, the company does not have the means to standardize the crimping. It has been found that small businesses do not possess the knowledge of equipment projecting, and often make long-term investments, possibly generating financial difficulties (Jugend, 2006; Toledo et al., 2008; Conforto et al., 2011).

Thus, this study has as main objective to present the development process of a crimping standardization equipment in the electronics industry. The specific objectives are: (i) to develop a prototype of a cable stripping equipment that targets cables with diameters varying from 1.5 to $5.0 \mathrm{~mm}$; (ii) to improve the quality of the manufactured product through the developed equipment; and (iii) to verify the productivity when comparing manual work to the functional prototype. 
In order for the proposed objectives to be achieved, some considerations are fundamental. The techniques and methods of product development were implemented considering a specific small company, therefore precedents for generalization should not be opened with the purpose of the work. The present study addresses only the crimping process phase. The economic viability of the equipment design, market research for future sales, supplier evaluations for scale production and equipment manufacturing are disregarded in this paper. In addition, investments in materials, labor, values of operations in machines and infrastructure are not counted, since the company's intention is to solve its problem quickly and efficiently, as well as the manufacturing through design software.

\section{Literature review}

This item aims to present the main concepts and methods that can be used in PPD. First, the techniques and methods of the product engineering segment that can be used in the PPD will be presented. In this context, the item was subdivided into the following topics: PPD management models, solution generation methods and value analysis engineering, evaluation of concepts generated from solutions aligned with value analysis and generation of models and prototypes according to the concepts created.

\subsection{Techniques used in the PPD}

Currently there are some useful tools for the effective operation of the PPD stages, which may or may not be fully applied depending on the product to be developed. The most relevant techniques found in the literature are the Brainstorming, the Gallery Method, the Morphological Method, the Mudge Method and the Decision Matrix, that in conjunction with tacit knowledge, provide a structure to support the evaluation and incorporation of new information during the development process (Rozenfeld et al., 2006; Silva, 2014; Borges \& Rodrigues, 2010; Pahl et al., 2005; Bataglin, 2012; Kist \& Andrade, 2017). Such techniques will be detailed in the following.

\subsubsection{Requirements generation - Brainstorming}

The main objective of brainstorming is to explore and capture new ideas, whether or not they are plausible. This technique works with the process of separating ideas from their possible criticism from a group of individuals, whose experiences and abilities relate to the same purpose (Rozenfeld et al., 2006). This group has as a goal the resolution of a specific problem that should be clearly exposed. Then the production of free ideas is stimulated and at the end of the preprogrammed time the analysis and classification of the generated data is done. This means of generating ideas is based on the fact that diversity of opinions enriches the creation process, since different people have different cultures and ways of life, which provides the generation of diverse perspectives on the same theme (Rozenfeld et al., 2006; Pahl et al., 2005). As such, it is an important form of interaction between the company and its clients in the important phases of the PPD (Morano et al., 2010).

Several studies have shown the applicability of brainstorming in the PPD. Cristo (2009) exemplifies and explains this technique used to generate help to designers in the creation of ideas and requirements in case studies that aims to generate an 
instrument for the construction of future public policies. Vanin et al. (2017) used brainstorming to generate development alternatives for a park bench that could be exposed to environment, whose results showed the applicability of the method to the generation of innovative ideas.

\subsubsection{Gallery method}

The Gallery Method is indicated to solve design problems in the conceptual, configuration and detailed design phase, as it generates solution proposals in the form of drawings that in turn are more easily understood. In addition, this technique is indicated for simple problems wen, in most cases, the components and the final form of the project are already defined (Cunha, 2011). For exemplification purposes, examples of Pahl et al. (2005), Vanin et al. (2017) and Cunha (2011), in which a study is focused on the analysis of the management of product ideas to support innovation planning using the method described.

\subsubsection{Morphological matrix}

The morphological matrix is a qualitative technique used with the intention of structuring and evaluating existing relationships in a problem. Such technique is also seen as a systematic approach that aims to analyze the generated ideas structure. This method is based on five steps (Figure 1), aiming at cataloging the various solutions to the problem and at the same time serving as a consultation source so that the designer does not deviate from the already proposed plan (Zavadil et al., 2014; Rodrigues, 2009).

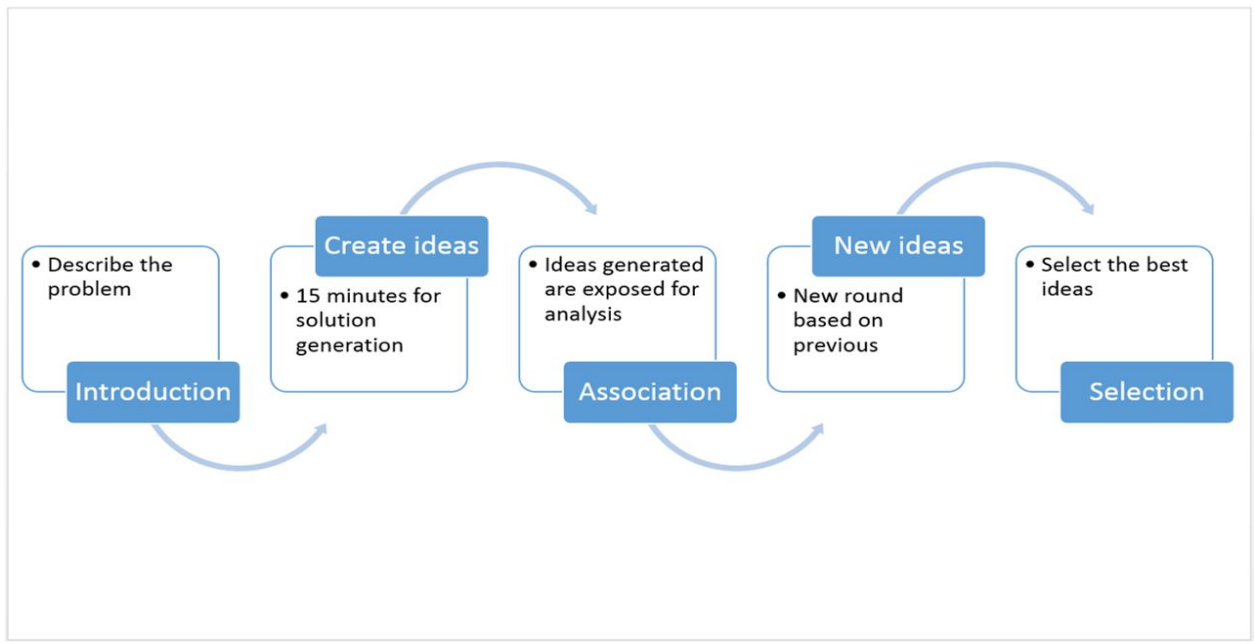

Figure 1. Steps of the Morphological Method. Source: Elaborated by the authors based on the literature (Pahl et al., 2005; Zavadil et al., 2014).

Zavadil et al. (2014) used the morphological method with the goal of generating ideas focused on the brand design segment, with the creation of logos and symbols focused on business marketing. The authors make an analysis on the options that the morphological matrix presented to transform this data into a more adequate solution, 
which contemplates the great majority of the requirements generated by the interested parties in the project. Kist \& Andrade (2017) used the morphological method to catalog the possible solutions for redesigning a cap repositioning equipment, which contributed to the choice of the best solution considering the criteria established by equipment users.

\subsection{Value engineering - the Mudge Matrix}

The Mudge Method, also known as numerical method of functional relations, is largely used when many functions of specific resources are enumerated, and it is necessary to classify them by means of the establishment of priorities (Rozenfeld et al., 2006). The use of such method is relevant in the definition of one of several alternatives proposed, helping the designer to define the most important requirements. Therefore, the main objective is to define the most relevant characteristic regarding the acceptance of the product, since this method can compare all the functions between them (Velho, 2010; Alvarenga, 2014).

An example can be seen in the study by Santos et al. (2008), in which the authors created priority requirements for ergonomy and safety in tractor station designs. In the work, the Mudge diagram was used in an attempt to perform a functional numerical analysis, aiming to prioritize functions that better meet the clients requirements, being defined that the convenience of the seats and the appropriately distributed control organs are respectively the most important criteria of the tractors studied.

\subsection{Concept evaluation - Pugh Method}

The concept evaluation, also called the Pugh Method, consists of evaluating the various conceptions of the projects considering both qualitative and quantitative aspects from the user's point of view (Pugh, 1995). However, there are difficulties in applying this technique in the conceptual design stage, since at this stage conceptions have few details (Pahl et al., 2005; Benassi \& Amaral, 2008).

Cutovoi \& Salles (2013) used the Decision Matrix to determine which of the previously selected concepts presents the best adherence to serve as a guidance system for a supply chain methodology. The selected concept must deliver the desired applicability, feasibility and pertinence.

In this way, it is verified that there are several tools that are used in order to structure the product development process and the analysis generated in it. Thus, the same will be applied in structuring the development of a customized industrial equipment, with functions and characteristics defined to solve the proposed problem, as will be presented in the next items.

\section{Methodological procedures}

This topic introduces the research and working methods. The research method classifies the research into four categories: (i) nature; (ii) approach; (iii) objectives and (iv) technical procedures. As for the work method, it explains how the work was structured, defining the steps, composed by their respective activities. 


\subsection{Research method}

This paper has the function of generating a prototype device for internal use of the company from a study of the PPD practical applications. Therefore, it has an applied nature, since it aims at forming specific knowledge in the solution of problems arising from the company's daily life (Santos, 2000). With regard to the technical procedures, action-research was adopted, since the company's reality was adapted in what studied process was concerned, with specific knowledge being generated from different perspectives. In addition, this method has an exploratory goal, since it provided the construction of creative methods and hypothesis elaboration objectives in the search for the best way of transforming the information into something tangible and functional (Gil, 2010). Additionally, the present paper has a qualitative-quantitative approach, since both qualitative product development and quantitative productivity analysis techniques were used to check the prototype's functional analysis.

\subsection{Work method}

The work method was defined using the works developed by Pahl et al. (2005), Borges \& Rodrigues (2010), Rozenfeld et al. (2006), Zavadil et al. (2014) and Velho (2010), whose main steps are presented in Figure 2. The works of Pahl et al. (2005) and Rozenfeld et al. (2006) served as a basis for identifying the most important phases and generating results of adequate visibility for the project team, leaving aside the steps of failure analysis, production preparation, product launch and post-development stages, which would not be relevant to the company. Besides, additional precautions were taken during the prioritization process in order to adjust the generated data so that the prototype would not need to be discarded if there were any characteristics other than those specified.

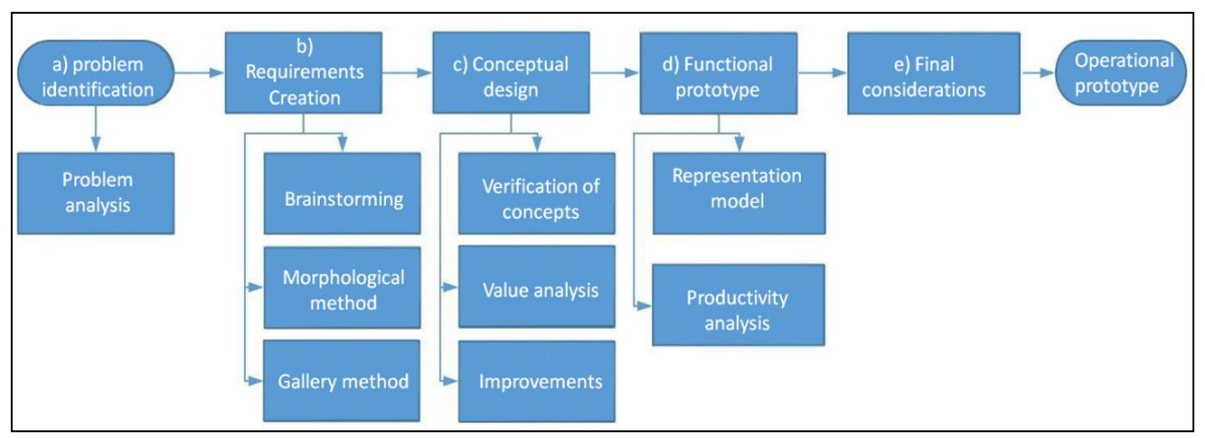

Figure 2. Research method. Source: Elaborated by the authors based on the literature (Pahl et al., 2005; Borges \& Rodrigues, 2010; Zavadil et al., 2014; Velho, 2010).

The activities related to each of the stages developed are:

a) Problem identification: this stage of the process was based on understanding the process that could be improved, based on a survey from customer complaints and suggestions of the defects history of the products that used stripped cables. Such a survey was done by one of the team's project engineering team participants. After that, the most common problems were listed, with tests being performed in order to verify the breakage of cables throughout the production process and final analysis before shipment; 
b) Requirements generation: in this stage PPD techniques were used, starting with brainstorming to generate ideas. After each participant presented their ideas for solving the problem of cable cutting, a debate was fomented between the parties involved in order to choose the most coherent ideas, considering mainly requirements and physical characteristics of the equipment. The gallery method was also used - in order to evaluate the main preliminary forms of the equipment and the morphological matrix, inducing the project team to maintain coherence between the ideas generated in the previous stages and the project requirements;

c) Conceptual design development: at this stage the Mudge matrix was used, which generated the most important characteristics that the equipment should have. An evaluation of the concepts through the use of the Pugh matrix was also performed to create the equipment based on the established rankings, and improvement actions on the conceptual prototype checking, according to ranking, the priorities that contribute to a greater impact on the equipment purpose;

d) Prototype development: in this stage, with the representation model already elaborated, a functional prototype was developed in real size and measurements were made in production process considering the quantity produced and quantity produced by rework, according to the company's manufacturing demand and with the purpose of generating data for later analysis;

e) Final considerations: This step is based on presenting an analysis of the results obtained in the previous steps with criticisms related to the advantages and disadvantages. In addition, a production analysis was performed by comparing the units produced and the quantity of non-conforming items over the established working time, using the two types of equipment, in order to verify the benefit brought by the operation's standardization.

\section{Practical application}

\subsection{Problem identification}

The company analyzed is located in Porto Alegre, whose main focus is the electroelectronic market with the manufacture of cables and special wire harnesses for the banking area. It currently has 12 employees, being 3 in the production sector, 2 in the administrative sector, 2 in the engineering sector and 5 in the software development sector, being classified as a small company. Cable production is performed according to customer specification; so all types of electric harnesses are customized.

The production process begins with the cutting of the cables according to the specified size; afterwards the cables are stripped and the ends are tinned. After that, the operator welds the cables into a splice plate, with the purpose of joining the cables before the thermoplastic material injection. Between each stage of the manufacturing process, continuity tests are performed to verify that no cable is broken.

During the manufacturing process it was found that there were a large number of products rejected in quality control tests. After an analysis on the equipments components it was verified that the problem was in the process of cutting and welding due to the lack of quality in stripping the internal parts of the cables. It was also observed that when the cable was cut by an operator the results were not satisfactory: the tool used presented a variation in force and positioning of the cable, because said 
cable was positioned by the operator. These variations resulted in unplanned cuts (Figure 3), crushing of the inner cable layers, and lack of pattern in the size of the stripping, which resulted in the risk of short circuit in the weld.
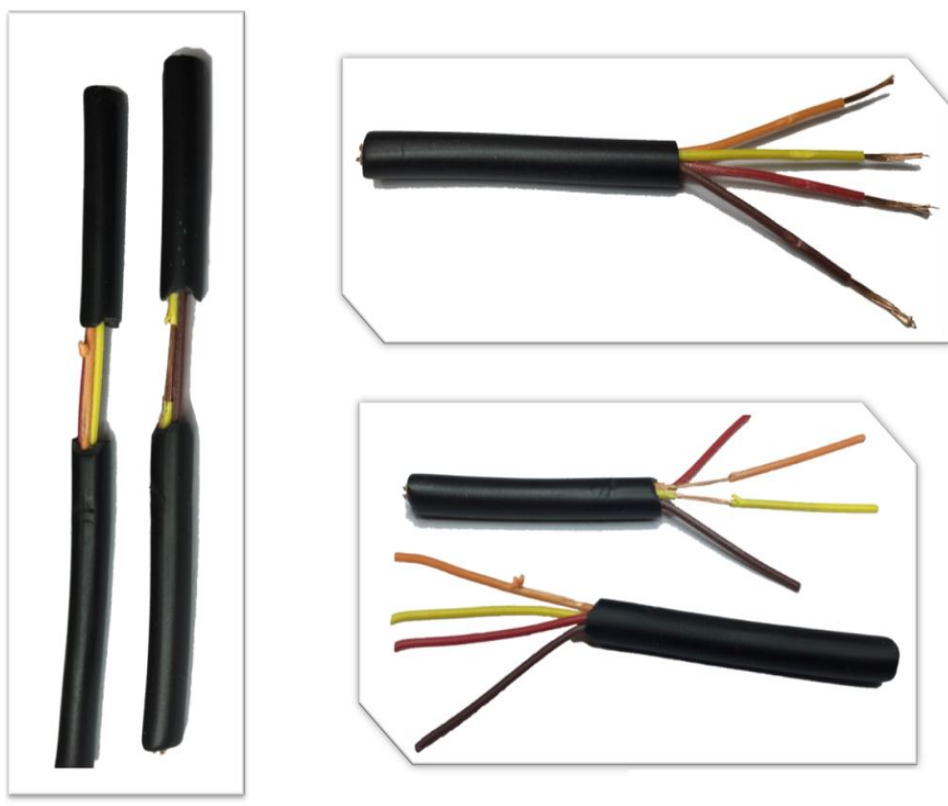

Figure 3. Operation defects.

The moment the collaborator welded two cables, the inner jacket that had been correctly stripped and presented crushing retracted and leaned on another cable. However, some cables passed the tests and were sent to the thermoplastic injection process, where with the use of pressure and heat they joined together and created the short circuits.

\subsection{Requirements generation}

\subsubsection{Brainstorming}

Initially a group of three participants - two from the project engineering sector and the other from the production sector - proposed initial requirements to solve the problem and improve the equipment design. After registering these ideas, the participants held a debate in order to improve the suggestions presented or propose new solutions according to the initial idea. In the end the ideas were counted and written in a table format (Chart 1) to ensure there was a sequence in the design process, as well as better visualization by all participants. 
Chart 1. Ideas generated through brainstorming

\begin{tabular}{|c|c|c|c|}
\hline & \multicolumn{3}{|c|}{ Requirements } \\
\hline $\begin{array}{l}\text { Participant } 1 \\
\text { (Engineering) }\end{array}$ & $\begin{array}{l}\text { Must be lightweight } \\
\text { Fast } \\
\text { Robust } \\
\text { Trustworthy } \\
\text { Cables from } 1.5 \mathrm{~mm} \\
\text { to } 5.0 \mathrm{~mm} \text { in } \\
\text { diameter }\end{array}$ & $\begin{array}{l}\text { Mechanism to } \\
\text { remove the covered } \\
\text { cable } \\
\text { Adjustable } \\
\text { mechanism } \\
\text { Pneumatic }\end{array}$ & $\begin{array}{l}\text { Use of low electrical } \\
\text { voltages } \\
\text { Low energy cost } \\
\text { Easy transport } \\
\text { Silent } \\
\text { Without rework }\end{array}$ \\
\hline $\begin{array}{l}\text { Participant } 2 \\
\text { (Engineering) }\end{array}$ & $\begin{array}{l}\text { Drop resistant } \\
\text { Electronic } \\
\text { Silent } \\
\text { Various types of } \\
\text { cables }\end{array}$ & $\begin{array}{l}\text { Easy triggering } \\
\text { Secure the cable } \\
\text { Pneumatic with } \\
\text { electronic control }\end{array}$ & $\begin{array}{l}\text { Simple maintenance } \\
\text { Adjusting the } \\
\text { removal size of the } \\
\text { cover }\end{array}$ \\
\hline $\begin{array}{l}\text { Participant } 3 \\
\text { (Production) }\end{array}$ & $\begin{array}{l}\text { Simple } \\
\text { Easy to use } \\
\text { Easy to clean } \\
\text { Light } \\
\text { Do not deform the } \\
\text { cable }\end{array}$ & $\begin{array}{l}\text { Use at the work } \\
\text { station } \\
\text { Own lighting } \\
\text { Safety } \\
\text { No adjustment } \\
\text { required }\end{array}$ & $\begin{array}{l}\text { Does not use } \\
\text { operator force } \\
\text { Remove the multi- } \\
\text { cable cover } \\
\text { Adjustable }\end{array}$ \\
\hline
\end{tabular}

According to the data generated, it was possible to choose, over the course of three meetings, the most relevant requirements for the equipment: ease of use, adjustment of stripping size, ease of transportation and maintenance, wear resistance, electronic activation control, pneumatic pistons whose function is to apply the force similarly to what the operator does during manual stripping, quietness, safety, reliability and light weight.

\subsubsection{Morphological method}

The morphological method was developed by two members of the engineering sector, aiming to develop several simple solutions alternatives that were combined to generate the best solution. Figure 4 shows the equipment modules: the base, the control board, the activation key, among others, according to the materials that the company had to make each piece. Those materials were used as consultation source by the designers, who sought to develop the project in a simpler and easier way. 


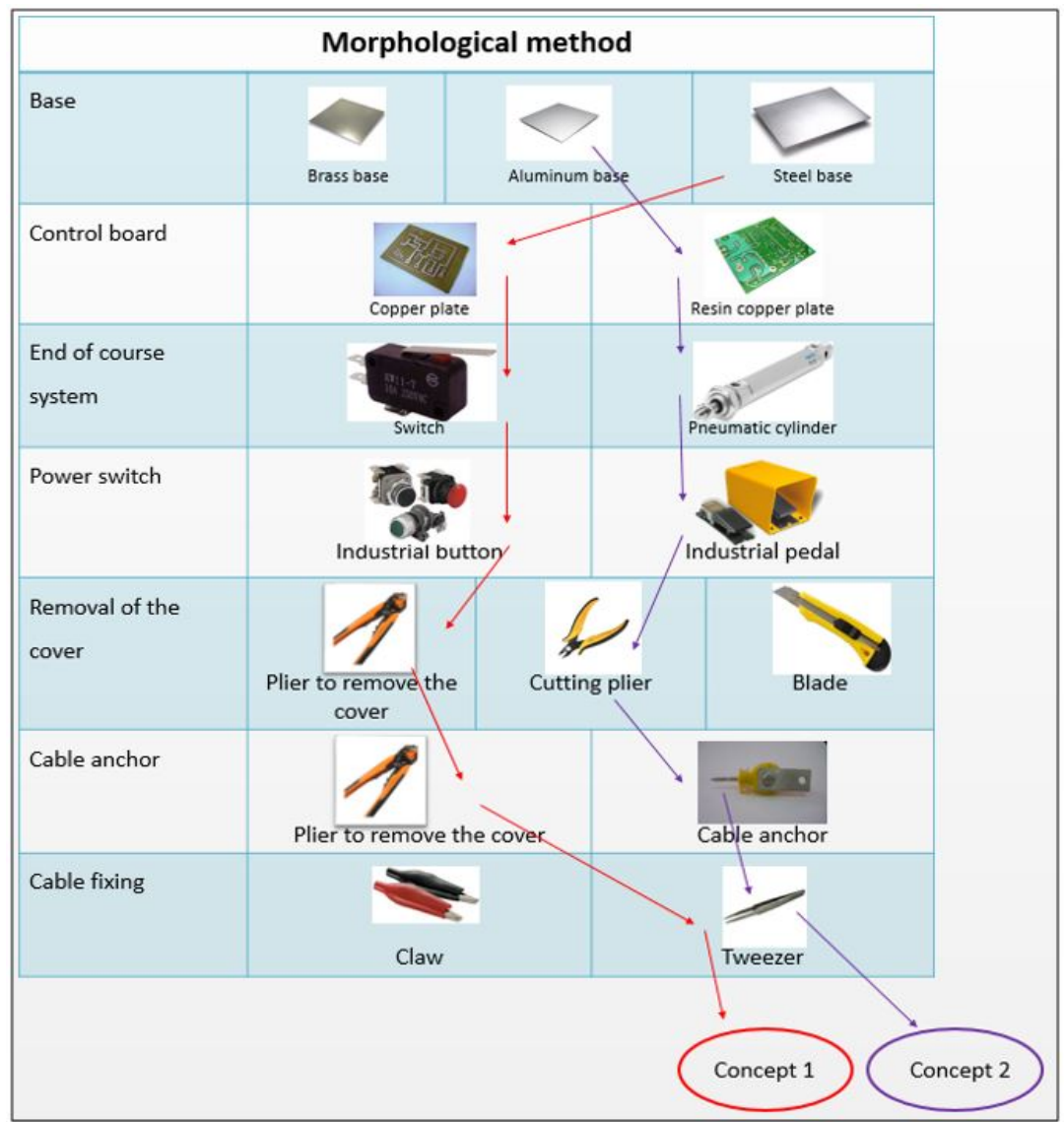

Figure 4. Morphological matrix.

The matrix in Figure 5 represents the two paths followed by designers in the engineering sector to create conceptual models that will be exemplified in the next topic.

\subsubsection{Gallery method}

At this stage the two participants from the project engineering sector were responsible for creating and proposing a new equipment part. Each of the participants clearly outlined the basic profile of the equipment under development, naming some key components needed for operation. Two types of equipment were presented that could be manufactured according to the functional, design and requirements of the brainstorming step, as shown in Figure 5. 


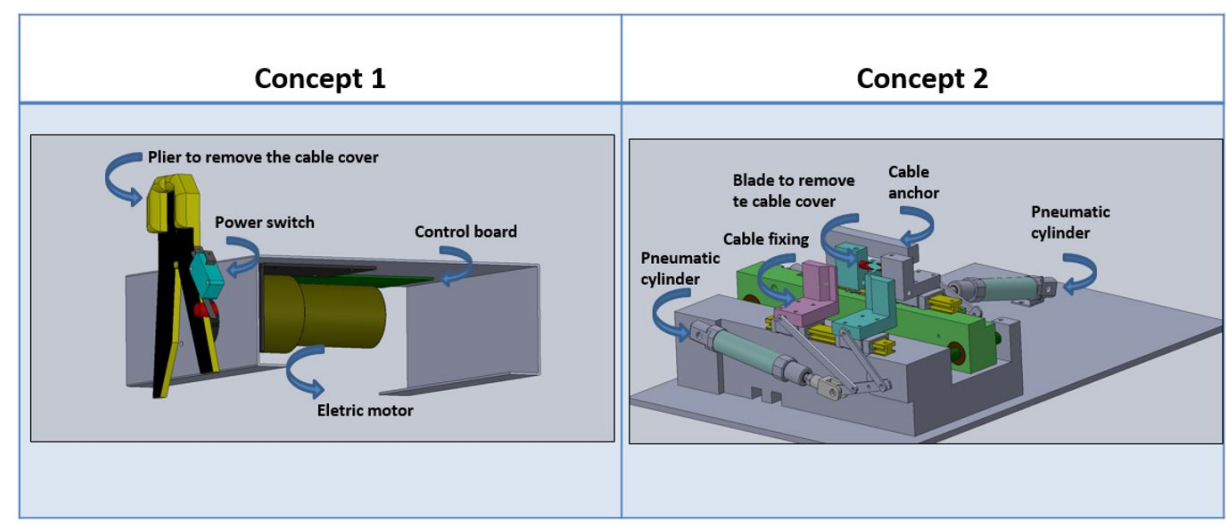

Figure 5. Gallery method indicating the generated concepts.

Concept 1 (Figure 5) has as its main characteristic the electric power, since after pressing the start button the motor will rotate transmitting force to the pliers that will remove the jacket. However, the cable must be positioned and held by the operator. As for concept 2 (Figure 5), it has the force exerted by pneumatic pistons, which generate less noise for the operator, and does not require him to hold the cable at the time of stripping, since there is a clamping holder for this task. In addition, this concept allows for a better adjustment of the size of the stripping because there is a cable stop for its standardization.

\subsection{Conceptual design}

\subsubsection{Pugh method}

Since it is an equipment adapted to the company in question, without the existence of similar equipment on the market, the concepts generated in the gallery method were compared to a reference concept, which was the manual stripping plier, that presents a similar function to the designed equipment. The concepts used in the Pugh Matrix are the concepts developed in the Gallery Method (Figure 5). For the establishment of weights associated with the main characteristics of the product, the symbology presented in Chart 2 was used to indicate which concepts presented advantages, disadvantages or equivalence with the reference concept.

Chart 2. Weights adopted in Pugh matrix.

\begin{tabular}{|c|l|}
\hline \multicolumn{2}{|c|}{ Symbology } \\
\hline+ & Advantage over the concept of reference \\
\hline $\mathbf{-}$ & Disadvantage about the concept of reference \\
\hline $\mathbf{0}$ (similar) & Equivalent to the concept of reference \\
\hline
\end{tabular}

Chart 3 shows the results of the Pugh Method, in which concepts 1 and 2 (Figure 5) were compared to the reference concept. 
Chart 3. Pugh matrix.

\section{PUGH MATRIX}

\begin{tabular}{|c|c|c|c|c|}
\hline Project Requirements & Points & $\begin{array}{l}\text { Concept } \\
1\end{array}$ & Concept 2 & Concept of reference \\
\hline $\begin{array}{l}\text { Adjusting to remove } \\
\text { the cable cover }\end{array}$ & 3 & 0 & + & Hand plier \\
\hline Weight (kg) & 1 & -1 & -1 & \\
\hline Transport & 1 & + & -1 & \\
\hline Safety & 5 & + & + & \\
\hline Simple use & 5 & + & + & \\
\hline Precision & 3 & 0 & + & \\
\hline Easy operation & 3 & + & + & \\
\hline $\begin{array}{l}\text { Cable cover } \\
\text { removal speed }\end{array}$ & 1 & -1 & -1 & \\
\hline Low rework & 5 & 0 & + & \\
\hline $\begin{array}{l}\text { Standardize the } \\
\text { time to remove the } \\
\text { cable cover }\end{array}$ & 3 & 0 & + & \\
\hline Low maintenance & 3 & +3 & + & \\
\hline Total & & 15 & 27 & \\
\hline
\end{tabular}

It is verified that concept 2 presented a larger sum and, therefore, was better when compared to main attributes. It should be noted that concept 2 lost score mainly in the weight and transportation requirement, but gained points in the most important requirements in relation to the characteristics desired in the equipment (stripping adjustment, precision, rework rate and standardization of stripping time).

\subsubsection{Mudge matrix}

The main aspects analyzed of the Mudge Matrix were the requirements generated previously by brainstorming and presented in Chart 4 in order to determine which requirements add more value to the project.

Chart 4. Basic functions of the equipment.

\begin{tabular}{cc}
$\begin{array}{c}\text { Equipment } \\
\text { functions }\end{array}$ & Summary of functions \\
\hline A & Remove the cable cover \\
\hline B & Adjust the cable cover removal \\
\hline C & Decrease weight (kg) \\
\hline D & Facilitate transportation \\
\hline E & Facilitate maintenance: Access to the most likely points to failure \\
\hline F & Less wear and tear on equipment \\
\hline G & Provide quick removal of the cable cover \\
\hline H & Be silent: Must work below permissible volume by law \\
\hline I & Provide simple drive \\
$\mathrm{J}$ & Provide removal of cable cover safely: It should not compromise the operator's \\
& physical integrity \\
$\mathrm{K}$ & Facilitate installation \\
\hline
\end{tabular}


When defining the equipment's basic functions a scale of importance was created assigning weights 1 (a slightly more important function), 2 (moderately more important function) and 3 (a much more important function) to the definition of priorities, and each one of the functions was compared to the other, generating a score. Afterwards it was possible to verify which were the most important functions and the ones that deserved to become a priority in the design of this equipment, as observed in Figure 6.

\begin{tabular}{|c|c|c|c|c|c|c|c|c|c|c|c|c|}
\hline \multicolumn{1}{c|}{} & B & C & D & E & F & G & H & I & J & K & TOTAL OF POINTS & \% \\
\hline A & A2 & A3 & A3 & A3 & A3 & A2 & A2 & A2 & J1 & A3 & 23 & 19.01 \\
\hline & B & B3 & B3 & B2 & B2 & B1 & B3 & B2 & J1 & B3 & 19 & 15.70 \\
\hline & & C & C3 & E3 & F1 & C1 & C2 & I2 & J3 & C1 & 7 & 5.79 \\
\hline
\end{tabular}

Figure 6. Function evaluation matrix.

It was verified that the function A (stripping of the cable) is the one that adds more value to the product, since it obtained a score of $19.01 \%$ besides being directly related to the objective of the equipment, followed by the $\mathrm{J}$ function (safely stripping), with $18.18 \%$ of the points. The functions $B$ (stripping adjustment), I (drive) and $E$ (serviceability) are directly related to the use of the equipment, and have obtained lower values only because they are secondary functions.

This matrix indicates that efforts should be devoted to the development and improvement of these characteristics. When analyzing the other values, it is verified that the functions $\mathrm{C}, \mathrm{D}, \mathrm{F}, \mathrm{G}, \mathrm{H}$ and $\mathrm{K}$ add small value to the product and can be revised throughout the project, improving according to future needs.

\subsection{Functional prototype}

By applying all the tools presented in the previous items it was possible to define both the characteristics and the functions needed for a perfect operation of the equipment. Figure 7 illustrates the functional prototype, which is in operation in the company.

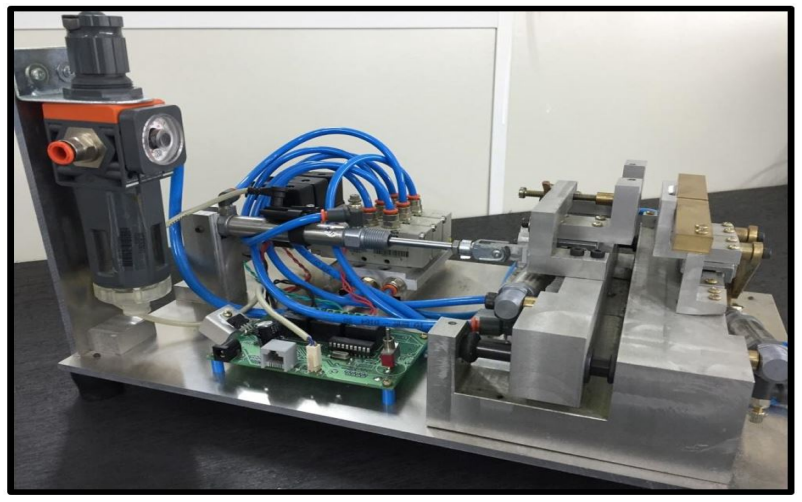

Figure 7. Prototype developed. 
This equipment was developed within the company over a three months period, with the contribution of two members of the engineering sector and a member of the production team. The engineering representatives were responsible for the sizing of parts, electronic design and purchase of materials. The member of the production sector was responsible for making the aluminum pieces and assembling the whole prototype. After the equipment was manufactured, both sectors involved in the project met for tests in order to verify the correct functioning of the device.

\subsubsection{Improvement actions}

From the prototype, the priorities defined in the Mudge Matrix were used to concentrate efforts on functions improvement, in order to add greater functional value to the equipment. Following are the improvement actions for the functions deemed necessary by the project team members:

- Function B (Stripping adjustment): A screw with a millimetric thread has been added to the cable stop (Figure 8), so that as the screw is tightened and the stop is directed forward, reducing the stripping size. When releasing the screw the stripping size increases, and on top of that a mechanical lock was inserted in the screw itself as to guarantee constant stipping measures. A cable positioner has also been added so that the operator does not need to hit the target on the stopper for the correct stripping, reducing machine cycle time and increasing productivity.

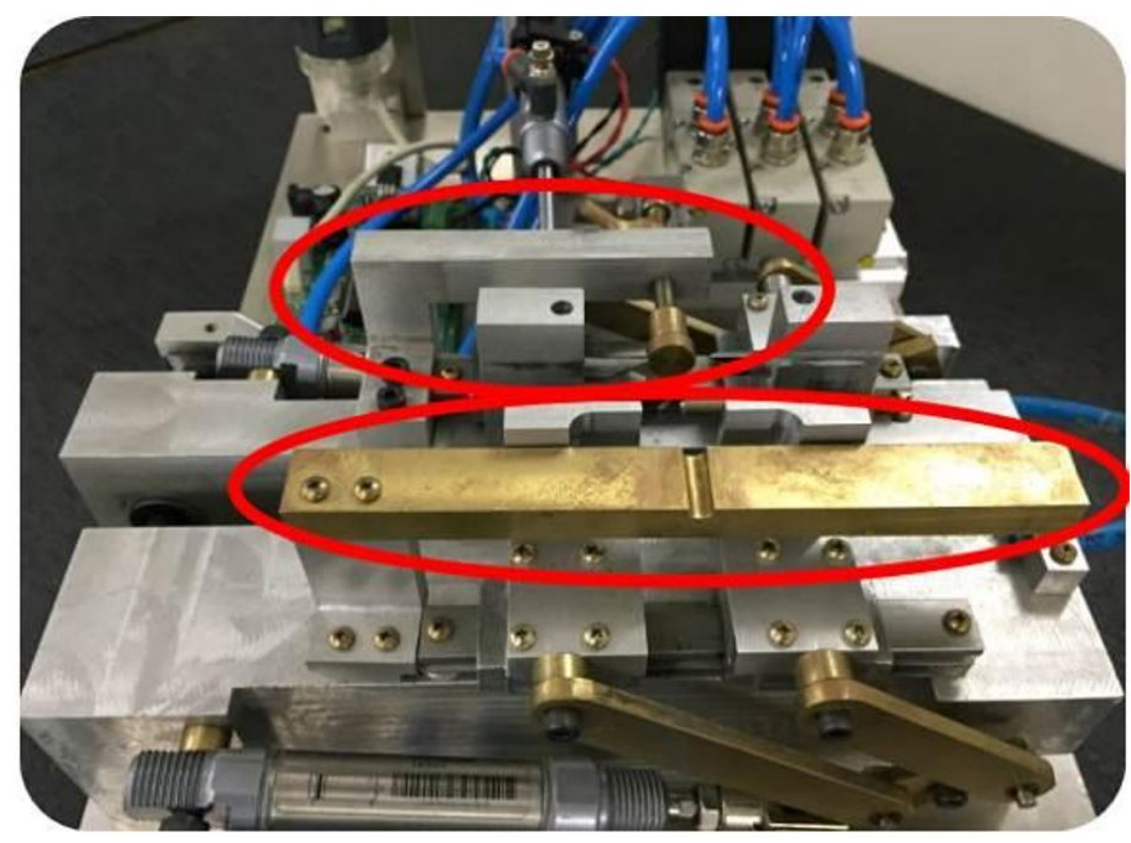

Figure 8. Adaptations made in order to improve the stripping process.

- Function I (Activation): with the use of the equipment it was verified that the operator needed to have one free hand in order to handle cables with length of more than two meters that required more care. This context prompted a change in the activation button, that was replaced with a connector to attach an industrial pedal, 
changing the drive from the hand to foot. This improvement change allowed the operator to gain agility and dexterity;

- Function J (Safely stripping): Due to the large forces involved in the compressed air pistons, the production sector representative noted the need to create a protection for them. Using a $1.5 \mathrm{~mm}$ thick aluminum plate, a protective cover was made and fixed to the base and side of the equipment, as shown in Figure 9.

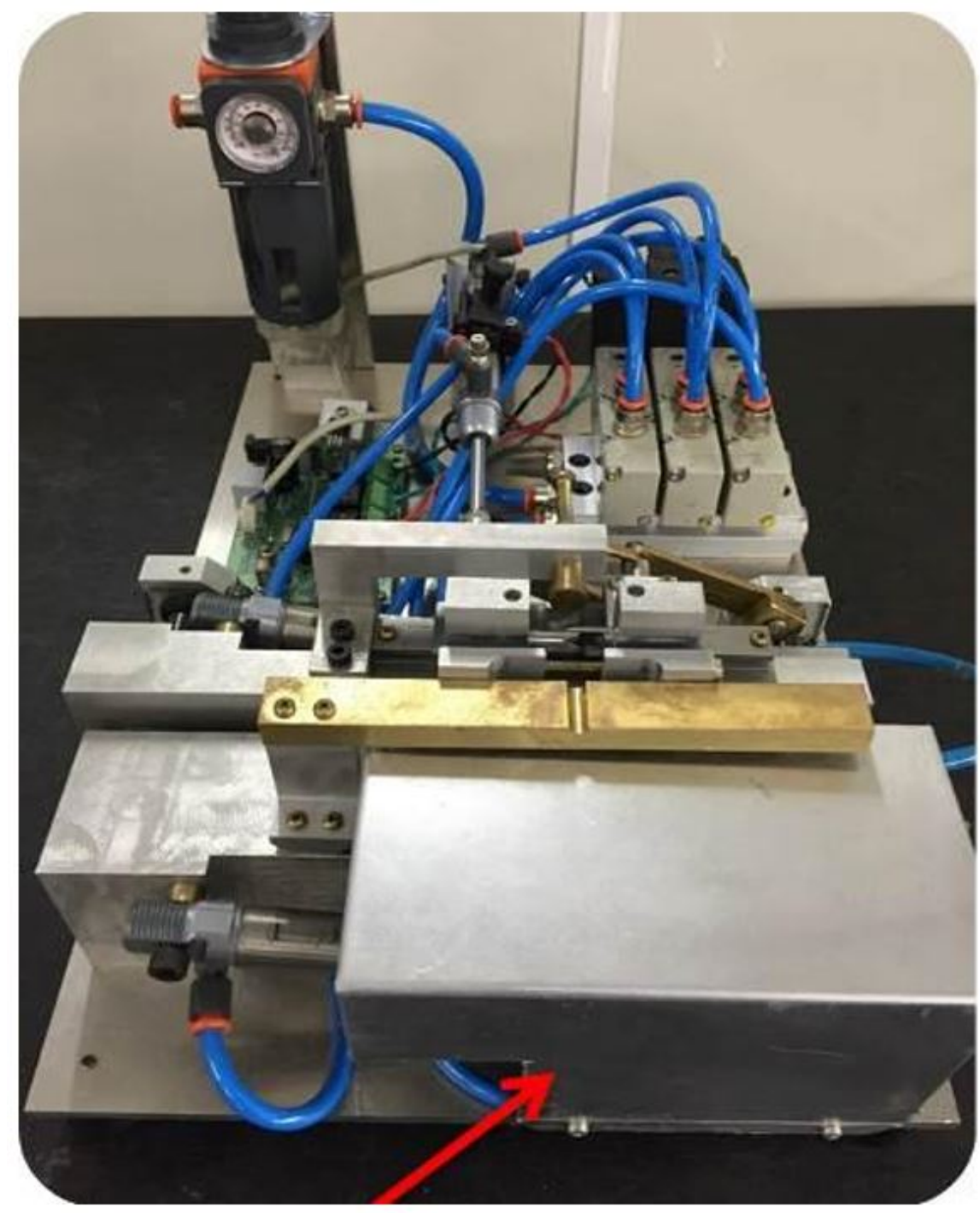

Figure 9. Protection for the stripping part.

- Function D (Transportation): because this equipment has a high weight due to the materials used, the simplest and most efficient solution was to place rubber feet of with $30 \mathrm{~mm}$ height at each end of the base, making the transportation easier by the operator. However, it was also noted that the edges of the base had an angle of ninety degrees that could cause cuts. The solution to this problem was to round the corners with fine sandpaper, reducing the risks to the operator; 
- Function E (Maintenance): the equipment presented some problems with stripping and of operation in the piece in which the stripping tool is fixed, due to the waste generated by previous strips that accumulated between the blocks (mobile and fixed), resulting in errors in the size adjustment of the cable. In order to solve this problem, a compressed air outlet was directed from the piston valve to the place of waste accumulation, by using a hose (Figure 10). In this way, after the stripping the valve released the air in order to push away any waste, minimizing the risk of malfunction. However, there was still a risk of the problem occurring, so the engineering sector added an on/off switch to the control board in order to keep the piston plunger retracted, making cleaning easier (Figure 11).

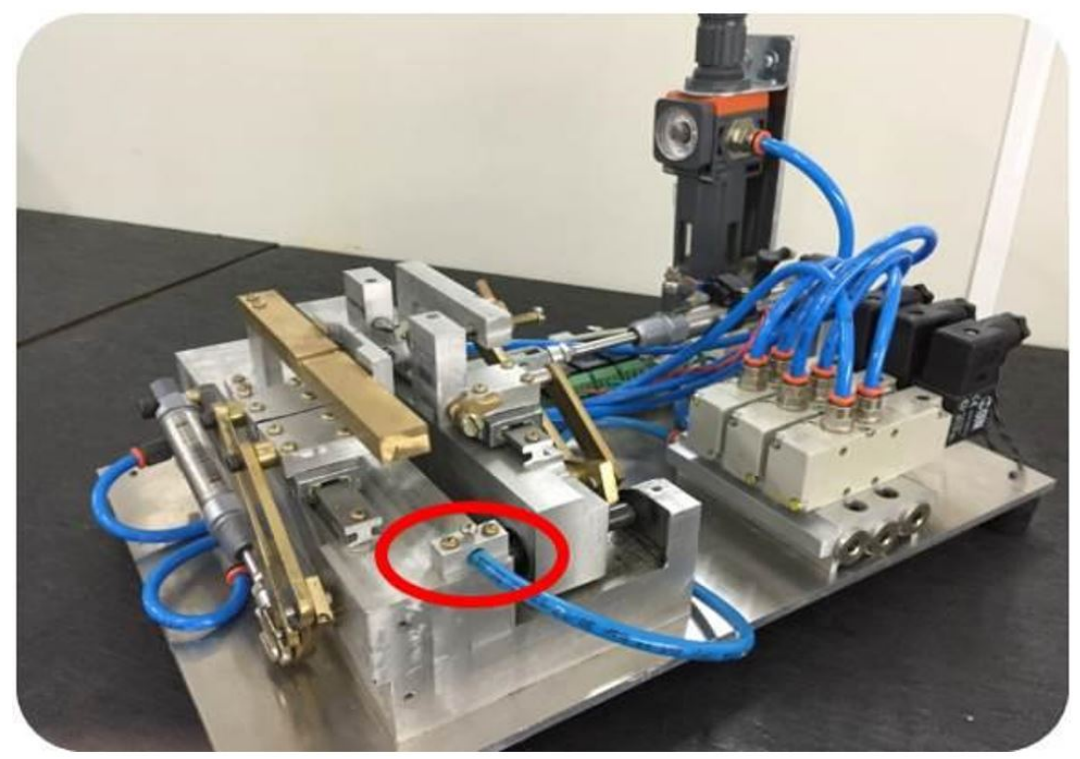

Figure 10. Adaptation for the cleaning of the waste area.

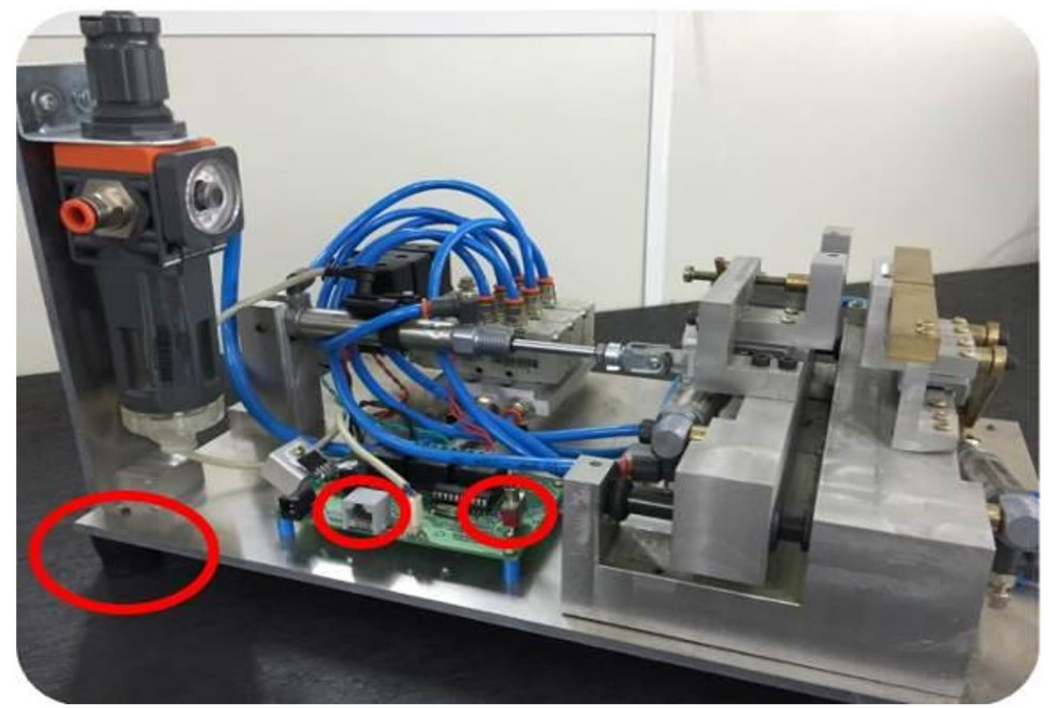

Figure 11. Set of implemented improvements. 
For the basic function A (stripping the cable) no improvement action has been performed, since it was considered adequate for its purpose. Besides, the steps of cutting the outer layer and stripping have been performed successfully and without errors.

\subsubsection{Productivity analysis}

After the equipment was fully functional in the production sector, daily measurements were made, measuring the volume of 5 millimeters diameter cables stripped with the hand pliers and the equipment by a specific operator in each work hour from January to May 2015. The working hours were established from eight in the morning to six in the afternoon, with an hour break for lunch and leisure.

With the production count already performed, the daily hourly average of each equipment's production was verified, aiming to define the average values of the operator's production in each hour measured. After these calculations, a table was created to analyze the data obtained (Table 1). Its objective was to verify the efficiency level of each equipment comparing the total production with both the defective adequate productions.

Table 1. Production comparison considering the two stripping methods.

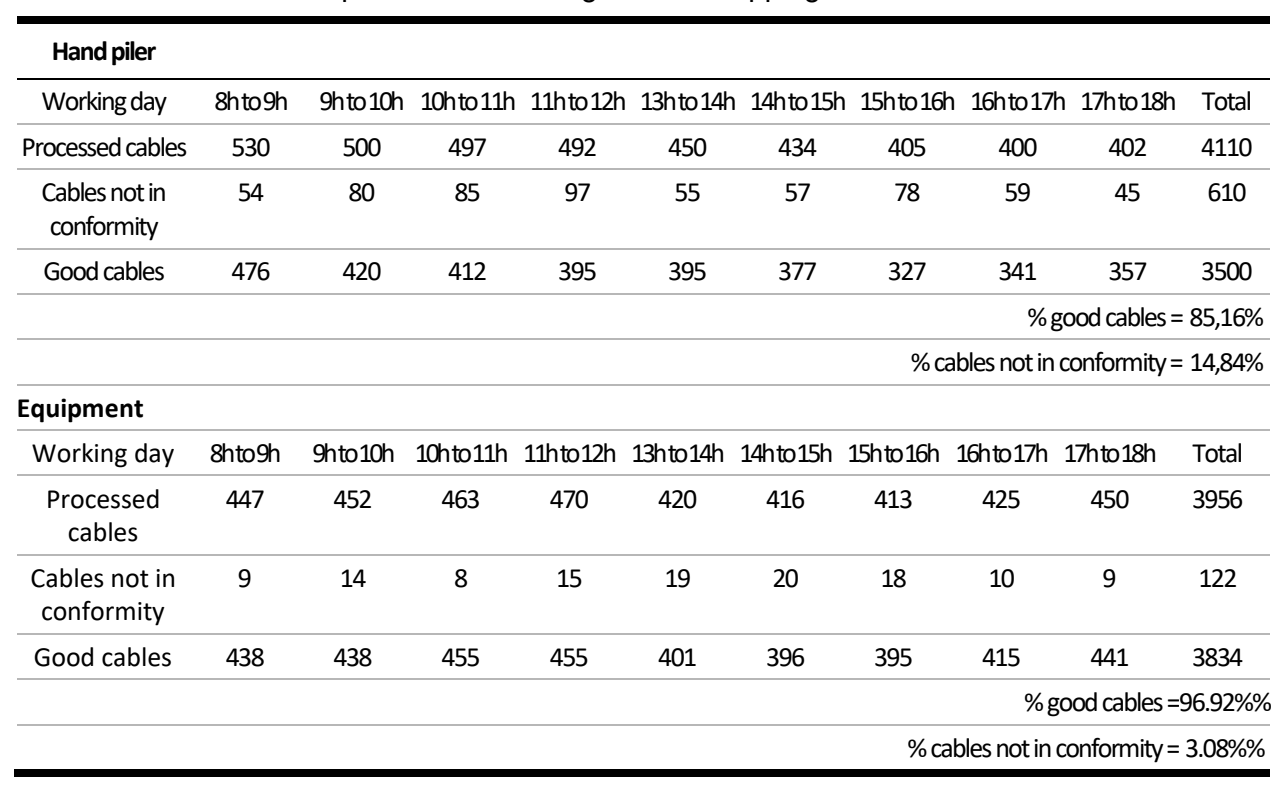

Figure 12 shows the 4110 cables stripped by the operator with the hand-held pliers. In this activity it is noticed that the operator started his journey with a high stripping number, which has decreased over time due to the operator's exhaustion, since handling the tool demands considerable strength. It is also verified that the defects number remained somewhat constant over time; from the 4110 cables stripped with the pliers, $85.16 \%$ were accepted for the next process and $14.84 \%$ needed repairing. 


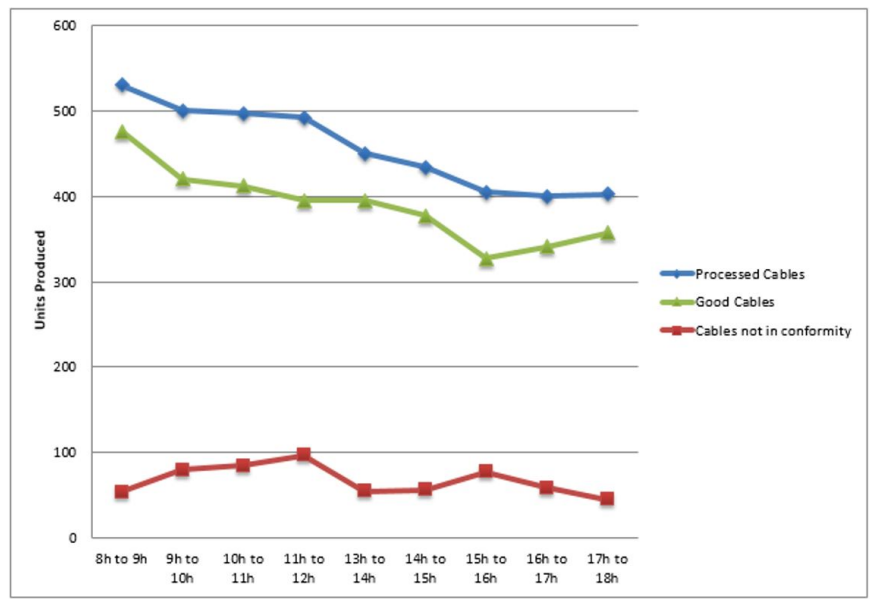

Figure 12. Number of cables stripped with manual pliers.

By using the prototype, the operator was able to lower the defects average compared to the operation performed with the hand-held pliers (Figure 13), since he did not need to apply force or use high concentration. The production variation along the work hours is perfectly acceptable as it is due to the need to clean the equipment when a lot of cable jacket waste is generated. This activity does not have influence over the cables production and final quality, since it demands low execution time.

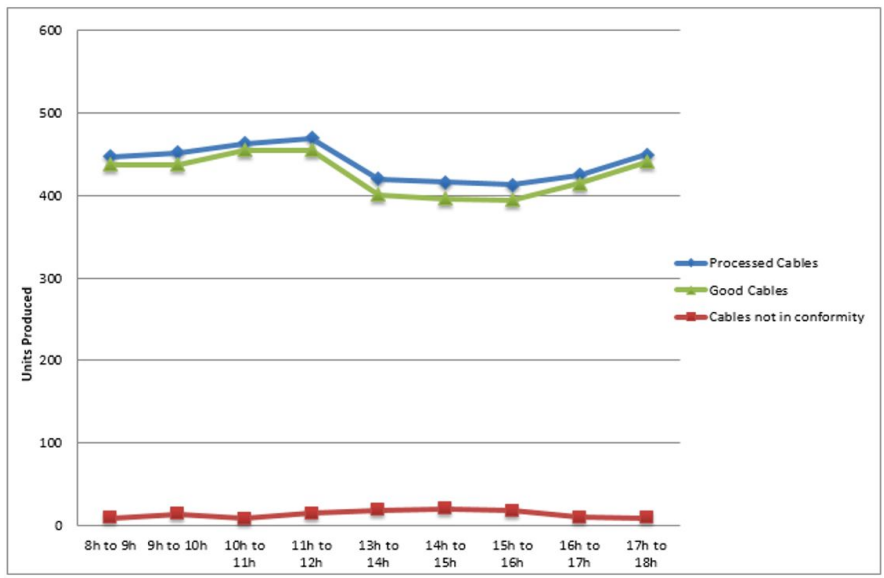

Figure 13. Number of stripped cables using the prototype.

Therefore, despite stripping a higher number of cables using the manual pliers (4110 cables), it was noticed that the use of this tool resulted in a lower approved production when compared to the prototype. It was also verified that the cable stripping speed is not an extremely relevant variable, since even with the equipment performing a smaller strippings count when compared to the pliers in the analyzed period - average from January to May, 2015 - it provides greater security so that the company can reduce rework time and cost. At the end of the day, when the two equipments are used in parallel, it can be verified that using the pliers is only feasible with small production batches, since the company has a competitive differential in its low delivery time. 


\section{Final considerations}

This work's main goal was to develop a prototype for the company's internal use from theoretical study and practical applications, using structured PPD tools and qualitative data together with two fundamental sectors of the company (Engineering and Production), which helped to identify the causes of product failures after the thermoplastic material injection tests and the improvement actions. In addition to that there is also the expansion of the work method applied, which is currently being used to solve another problem in the company. Based on the production and defects analysis it was possible to gather information considering two different perspectives. Initially it was verified that the use of the prototype results in a smaller percentage of defective cables when compared with the production; however, a lower stripping number was observed during the analyzed period. Using the manual pliers implies in larger production, but with a greater defects percentage. In this context, precedents are set for a quantitative analysis in order to verify the best suitability of production volumes for each equipment.

In this way, the use of these tools contributed to a better understanding of the PPD phases, resulting in knowledge dissemination within the company sectors in order to elaborate a standard and customized methodology to solve the problems that involve quality and productivity improvement. Using this knowledge opens precedents for future works based on the researches and case studies involving the PPD and manufacturing processes, the economic viability of a larger scale production and definition of investment values.

\section{References}

Alvarenga, T. H. P. (2014). Cenário da gestão da qualidade nos laticínios de micro e pequeno porte da região dos campos gerais no Paraná (Dissertação de mestrado). Universidade Federal do Paraná, Curitiba.

Bataglin, M. (2012). O método do desdobramento da função modular no projeto e manufatura sustentável de produtos: aplicação em uma empresa do setor metal-mecânico (Dissertação de mestrado). Universidade Federal de Santa Catarina, Florianópolis.

Benassi, J. L. G., \& Amaral, D. C. (2008). Avaliação de métodos de apoio à criação da visão do Produto no enfoque ágil de gestão de projetos. In Anais do $28^{\circ}$ Encontro Nacional de Engenharia de Produção (ENEGEP). Rio de Janeiro: ABEPRO.

Borges, F. M., \& Rodrigues, C. L. P. (2010). Pontos passiveis de melhoria no método de projeto de produto de Pahl e Beitz. Gestão \& Produção, 17(2), 271-281. http://dx.doi.org/10.1590/S0104-530X2010000200005.

Conforto, E. C., \& Amaral, D. C., \& Silva, S. L. (2011). Roteiro para revisão bibliográfica sistemática: aplicação no desenvolvimento de produtos e gerenciamento de projetos. In Anais do $8^{\circ}$ Congresso Brasileiro Gestão e Desenvolvimento de Produtos (CBGDP). Porto Alegre: IGDP.

Cristo, C. M. P. N. (2009). Prospectiva estratégica: instrumento para a construção do futuro e para a elaboração de políticas públicas. Revista do Serviço Público, 7(1), 37-63.

Cunha, V. P. (2011). Análise da gestão de ideias de produtos para apoiar o planejamento da inovação (Dissertação de mestrado). Universidade de São Paulo, São Carlos.

Cutovoi, I. T. M., \& Salles, J. A. A. (2013). Aplicação do método Pugh para a sistematização do PDP na cadeia de suprimentos numa empresa do segmento automotivo. In Anais do IX Congresso Nacional de excelência em gestão. Montes Claros: INOVARSE. Retrieved in 2017, March 22, from http://www.inovarse.org/sites/default/files/T13_0574_3140_0.pdf 
Gil, A. C. (2010). Como elaborar projetos de pesquisa (5. ed.). São Paulo: Editora Atlas.

Jugend, D. (2006). Desenvolvimento de produtos em pequenas e médias empresas de base tecnológica: práticas de gestão no setor de automação de controle de processos (Dissertação de mestrado). Universidade Federal de São Carlos, São Carlos.

Kist, G. P., \& Andrade, J. J. O. (2017). Projeto conceitual no processo de desenvolvimento de produtos (PDP): estudo de caso em um equipamento repositor de tampas na indústria de bebidas. Revista de Ciencia y Tecnología, 20, 39-36.

Morano, C. A., Martins, C. G., \& Ferreira, M. L. R. (2010). Aplicação das técnicas de identificação de risco em empreendimentos de E e P. Engevista, 8(2). http://dx.doi.org/10.22409/engevista.v8i2.198.

Pahl, G., Beitz, W., Feldhusen, J., \& Grote, K. (2005). Projeto na engenharia: fundamentos do desenvolvimento eficaz de produtos, métodos e aplicações. (6. ed., 432 p.). São Paulo: Edgar Blücher,

Pugh, S. (1995). Total design: integrated methods for successful product engineering. Boston: Addison Wesley.

Reis, P. P., Cheng, L. C., Ladeira, M. B., \& Fernandes, J. M. (2014). Contribuições ao processo de planejamento de negócio para a geração de empresas de base tecnológica de origem acadêmica (EBTS DE AO). Revista de Administração e Inovação, 11(4), 7-32.

Rodrigues, J. F. (2009). Influência das técnicas de criatividade nos resultados de inovação em uma empresa do ramo metalúrgico em Ponta Grossa - PR (Mestrado em dissertação). Universidade Tecnológica Federal do Paraná, Ponta Grossa.

Rozenfeld, H., Forcelline, F. A., Amaral, D. C., Toledo, J. C., Silva, S. L., Alliprandini, D. H., \& Scalice, R. K. (2006). Gestão de desenvolvimento de produtos: uma referência para a melhoria do processo. São Paulo: Saraiva.

Santos, A. R. (2000). Metodologia científica: a construção do conhecimento. Rio de Janeiro: DP\&A.

Santos, P. M., Schlosser, J. F., Romanol, L. N., Rozinll, D., Turattil, J. C., Witterl, M. (2008). Prioridades de requisitos para projeto de postos de operação de tratores quanto à ergonomia e segurança. Pesquisa Agropecuária Brasileira, 43(7), 869-877. http://dx.doi.org/10.1590/S0100-204X2008000700011.

Scoralick, M. C. L. (2004). Gestão do processo de desenvolvimento de produtos de empresas de pequeno porte de base tecnológica de são carlos: estudo de caso (Dissertação de mestrado). Universidade Federal de São Carlos, São Carlos.

Silva, R. R. B. (2014). Proposta de estruturação do processo de desenvolvimento de produtos para empresas prestadoras de serviço de telecomunicações (Dissertação de mestrado). Universidade Tecnológica Federal do Paraná, Ponta Grossa.

Toledo, J. C., Silva, S. L., Mendes, G. H. S., \& Jugend, D. (2008). Fatores críticos de sucesso no gerenciamento de projetos de desenvolvimento de produto em empresas de base tecnológica de pequeno e médio porte. Gestão \& Produção, 15(1), 117-134. http://dx.doi.org/10.1590/S0104-530X2008000100011.

Vanin, G. S., Prestes, G., Galarza, I. R., Rogrigues, R. A., \& Soares, H. M. (2017). Desenvolvimento de um produto: banco sujeito a condições de ambiente externo. In: Anais do XXXVII Encontro Nacional de Engenharia de Produção. Joinvile: ENEGEP.

Velho, C. O. (2010). Proposta de uma sistemática para escolha de um provedor de serviços lógicos (Dissertação de mestrado). Universidade Federal do Rio Grande do Sul, Porto Alegre.

Zavadil, P., Scherer, F. V., Teixeira, F. G., Silva, R. P., Koltermann, T., \& Cattani, A. (2014). Possibilidades de uso da matriz morfológica no processo de geração de alternativas em design. In Anais do $11^{\circ}$ Congresso Brasileiro de Pesquisa e Desenvolvimento em Design (CBPDD) (pp. 1-12). Gramado: UFRGS. 